\title{
Comparative Analysis of the Genomic DNA Isolation Methods on Inula sp. (Asteraceae)
}

\section{Emre SEVINDIK ${ }^{1 *}$, Fatih COSKUN², Zehra Tugba MURATHAN ${ }^{3}, \mathrm{M}$. Yavuz PAKSOY ${ }^{4}$,Veysel UZUN ${ }^{2}$}

\author{
1*Department of Agricultural Biotechnology, Faculty of Agriculture, Adnan Menderes University, Aydin, Turkey; ph.d-emre@hotmail.com \\ ( ${ }^{*}$ correspomding author) \\ ${ }^{2}$ Balikesir University, Department of Biology, Cagis Campus, Balıkesir, Turkey; fcoskun@balikesir.edu.tr \\ ${ }^{3}$ Ardahan University, Faculty of Engineering, Department of Food Engineering, Ardahan, Turkey; ztugbaabaci@hotmail.com \\ ${ }^{4}$ Tunceli University, Faculty of Engineering, Department of Environmental Engineering, Tunceli, Turkey; mypaksoy@gmail.com
}

\begin{abstract}
Simple, fast, low-cost and high throughput protocols are required for DNA isolation of plant species. In this study, phenol chloroform isoamyl alcohol and commercial (Sigma) DNA isolation kit methods were applied on some Inula species that belong to Asteraceae family. Genomic DNA amounts, $A_{260}, A_{280}, A_{260} / A_{230}$ and purity degrees $\left(A_{260} / A_{280}\right)$ that were obtained through both methods were measured through electrophoresis and spectrophotometer. Additionally, PCR amplification was realized by primer pairs specific to nrDNA ITS, cpDNA $n d b \mathrm{~F}$ (972F-1603R) and $\operatorname{trn} \mathrm{L}-\mathrm{F}$ regions. Results showed that maximum genomic DNA in nanograms obtained by phenol chloroform isoamyl alcohol method. The study also revealed that I. macrocephala had the maximum DNA and I. heterolepis had the minimum DNA amount. $\mathrm{A}_{260} / \mathrm{A}_{280}$ purity degrees showed that the highest and lowest purity in gDNAs obtained through phenol-chloroform isoamyl alcohol method were in I.aucheriana and I. salicina, respectively. The highest and lowest purity degrees of gDNAs obtained through commercial kit was observed in I. fragilis and I. macrocephala samples, respectively. PCR amplification results showed that while band profiles of each three regions (ITS, trnL-F and $n d h \mathrm{~F}$ ) did not yield positive results in PCR amplifications using phenol-chloroform isoamyl alcohol method; PCR band profiles obtained through commercial kit yielded positive results. As a result, it is fair to say that the relation of genomic DNA with PCR was found to be more efficient although the maximum amount of genomic DNA was obtained through phenol chloroform isoamyl alcohol method.
\end{abstract}

Keywords: amplification, commercial kit, genomic DNA isolation, Inula, PCR

\section{Introduction}

Polymerase chain reactions have brought about radical changes in molecular biology and genetic studies for plants, animal and many microorganisms. Usage of molecular markers such as RAPD, ISSR, RFLP, SSR and QTL in plant breeding, PCR based DNA marker analysis, some crop plants, populations and species for genetic diversity and mapping studies with the development of PCR based markers within the last years has paved the way for many different studies (Lee, 1995; Sant et al., 1999; Francia et al., 2005; Liu et al., 2005; Dwivedi et al., 2007; Mackill, 2007; Akhtar et al., 2010; Vural and Akçın, 2010). Characteristically, a considerable number of plaint species contain a significant level of polysaccharides, terpenes, polyphenols and other secondary metabolites. It was revealed that these substances bind to nucleic acids firmly during DNA isolation and inhibit Taq- polymerase enzyme and block PCR amplification (Fang et al., 1992; Pirttila et al., 2001; Kermekchiev et al., 2009). For this reason, it is particularly essential to obtain DNA material to be used in the studies within a short time and in a pure form. A simple, rapid, low-cost, high yield protocol with minimum contamination and high safety is needed for DNA isolation of any plant species. The process of obtaining genomic DNA includes steps such as eliminating the cell membrane, disintegrating and removing the proteins and purifying the DNA after precipitation. Various chemicals must be used in different amounts in order to apply these methods (Bailes et al., 2007).

Genus Inula belongs to Asteraceae family and is distributed throughout the world. Many species of this genus are being used by the local people for different purposes. The species of this genus are known for anticancer, antibacterial, cytotoxic 
and anti-inflammatory properties. The investigation on Inula species has brought various significant bioactive components of this genus into view. These components are sesquiterpenes, lactones, flavonoids, glycosidases and phenolic compounds (Ulubelen et al., 1987; Vajs et al., 1989; Shao et al., 1996; Ahmed et al., 2003; Qi et al., 2008). It is difficult to obtain pure genomic DNA from these species, which are rich in secondary components. This is because their compounds pose barrier to obtain pure DNA and block successful PCR reaction. Various studies are being conducted and methods are being developed in order to prevent such disadvantages. The aim of this study was to obtain DNA from species of Inula spp. (Asteraceae) with different methods, to multiply different gene regions of DNA samples obtained via two different methods with different primers, and to determine the suitability of the methods and primers. To fulfill this goal, two different genomic DNA isolation methods, which are phenol chloroform and commercial kit (SIGMA) methods, were applied on plant samples. Genomic DNAs obtained with two different isolation methods were multiplied via primers specific to ITS (nrDNA), trnL-F and $n d h \mathrm{~F}$ (972F-1603R) (cpDNA) regions, and it was determined which method was suitable for which primer. This study aimed to make contribution to the molecular biology, agricultural biotechnology and biochemical studies to be carried out in the years to come by optimizing DNA isolation method of some Inula species, which are economically valuable due to the secondary compounds that they contain.

\section{Materials and Methods}

\section{Plant samples}

All plant materials used in this study were collected from different localities in Turkey during field works from Summer 2013. A total of 12 taxa ( 6 endemic taxa) Inula accessions were used in the current study. For each population collection of information related to the region and subgenera are shown in Table 1.

\section{DNA extractions \\ Isolation with modified phenol chloroform issamyl alcohol protocol}

Dellaporta et al. (1983) modified and used DNA isolation method. In this method, almost 1 gr leaf tissue is crushed within liquid nitrogen. The samples crushed are put into eppendorf tubes, and $600 \mu \mathrm{l}$ isolation buffer is added and dissolved. $500 \mu \mathrm{l}$ phenol chloroform isoamyl alcohol were added onto the sample within the tube and centrifuge is performed. Thus, proteins precipitate and DNA rises to the top. The supernatant formed is decanted to the new tube and $3 \mathrm{M} \mathrm{NaAc}, \mathrm{pH}=5.2$, which equals to the $10 \%$ of supernatant volume, is added into it. $500 \mu \mathrm{l}$ isopropanol is added. At this phase, DNA is seen with naked eye. DNA is precipitated through centrifuge, and pellet is formed on the bottom. The solution on the top is decanted into the waste bottle. $500 \mu \mathrm{l} \mathrm{TE}$ $(10 \mathrm{mM}, \mathrm{pH}=8)$ is added into the pellet formed (It is required to dissolve with pipetting). $5 \mu \mathrm{RNaz} A$ is added and the tube is turned upside down. Lipoid layer is made homogeneous after pipetting. It is incubated $37^{\circ} \mathrm{C}$ for 30 minutes and RNA is migrated away. Later on, $50 \mu \mathrm{l} \mathrm{NaAc}(3 \mathrm{M})$ is added and tube is turned upside down. Later on, $1 \mathrm{ml} \mathrm{90 \%} \mathrm{ETOH} \mathrm{is} \mathrm{added} \mathrm{and}$ the tube is turned upside down. It is kept for 10 minutes at -80 ${ }^{\circ} \mathrm{C}$ and precipitation is achieved by performing centrifuge when the waiting time is over. Ethanol is decanted. Supernatant on the top is put into waste bin, and the pellet settles to the bottom. The remaining solution is washed with $70 \% \mathrm{ETOH}$ (by performing pipetting) and centrifuge is performed. The ethanol on the top is removed after centrifuge and pellet settles on the bottom. The pellet formed is washed with $90 \% \mathrm{ETOH}$ and centrifuge is performed. Following centrifuge, the ethanol on the top is removed. Once again, pellet is washed with $90 \%$ ETOH and centrifuge is performed. Later, ETOH is removed and pellet remains. The pellet settled on the bottom is put on the blotting paper and the ethanol is evaporated. Lastly, $50 \mu \mathrm{l}$ TE is added on the pellet on the bottom and is made ready for use after dissolving properly.

\section{Isolations with Sigma DNA isolation kit}

Plant samples were isolated by using SIGMA G2N70 Plant Genomic DNA Miniprep Kit. After 1 gr plant sample is powdered with liquid nitrogen, $350 \mu$ l lysis solutions (Part A) is added on it. Next, $50 \mu$ lysis solution (Part B) is added onto it and vortex is performed. $4 \mu \mathrm{lNNa} \mathrm{A}$ is added onto this mixture. It is left to incubation at $65^{\circ} \mathrm{C}$ for 10 minutes in water bath. $130 \mu \mathrm{l}$ precipitation solution is added on the samples. They were put into ice for 5 minutes and centrifuge is performed consecutively. Liquid part is decanted to the blue filtered tube. Centrifuge is performed and column is removed and collection tube remains. $700 \mu \mathrm{l}$ binding solution is added and almost a total of $1000 \mu \mathrm{l}$ volume is formed. Later on, binding column is prepared. To this end, $500 \mu \mathrm{l}$ column preparation solution is added to the red columned tubes and centrifuge is performed. Collection tubes are removed and red filtered colons are taken. Thus, binding colon becomes ready. $700 \mu \mathrm{l}$ of the solution in collection tubes in the previous step is transferred to the new red columned tubes and centrifuge is performed and liquid is removed and collection tube remains. Red colons are put into collection tubes again. The remaining

Table1. Collection localities of the Inula taxa

\begin{tabular}{|c|c|c|c|}
\hline Taxa & Locations/Date & Taxa & Locations/Date \\
\hline $\begin{array}{c}\text { Inula helenium subsp. orgyalis } \\
\text { (Boiss) Grierson }\end{array}$ & $\begin{array}{c}\text { Kastamonu, Eflani, Turkey, } \\
01.08 .2013\end{array}$ & Inula heterolepis (Boiss) & $\begin{array}{c}\text { Manisa, Sipil Mountain, Turkey, } \\
\text { 26.07.2013 }\end{array}$ \\
\hline $\begin{array}{c}\text { "Inula macrocephala (Boiss \&: } \\
\text { Kotschy ex Boiss) }\end{array}$ & $\begin{array}{c}\text { Muş, Malazgirt, Turkey, } \\
15.08 .2013\end{array}$ & Inula fragilis (Boiss. \& Hausskn) & Malatya, Beydağı, Turkey, 14.08.2013 \\
\hline Inula inuloides (Fenzl) Grierson & Van, Çatak, Turkey, 16.08.2013 & Inula anatolica (Boiss) & Denizli, Pamukkale, Turkey, 27.07.2013 \\
\hline Inula salicina (Linnaeus) & $\begin{array}{c}\text { Konya, Taşkent, Turkey, } \\
27.07 .2013\end{array}$ & Inula sechmenii (Hartvig \& Strid): & Antalya, Turkey, 28.07.2013 \\
\hline Inula mariae (Bordz) & $\begin{array}{c}\text { Ağrı, Doğubeyazıt, Turkey, } \\
16.08 .2013\end{array}$ & "Inula discoidea (Boiss): & Muş, Malazgirt, Turkey, 15.08.2013 \\
\hline Inula britannica (Linnaeus) & $\begin{array}{c}\text { Çankırı, Atkaracalar, Turkey, } \\
01.08 .2013\end{array}$ & Inula aucheriana (DC) & Denizli, Pamukkale, Turkey, 27.07.2013 \\
\hline
\end{tabular}


446

$300 \mu \mathrm{l}$ solution is passed from the colon and centrifuge is performed. Liquid and colon are removed. Colon is inserted into a new collection tube in order to be washed. $500 \mu l$ wash solution is added and centrifuge is performed. Liquid is removed and collection tube remains. Wash solution is added again and centrifuge is performed. Liquid is removed and collection tube remains. Wash solution is added again and is centrifuged. Liquid is decanted without contacting the colon. Colon is placed into new collection tubes. $100 \mu$ l elution solution is added onto it and is centrifuged. The colon is decanted without contacting the liquid and is placed into the collection tubes. $100 \mu \mathrm{l}$ elution solution is added again and is centrifuged. Column is removed and DNAs are made ready to use.

\section{Determining purity and quantity of DNA samples}

The amount of the DNA samples isolated through two different methods was determined through gel electrophoresis. To this end, $0.8 \%$ gel electrophoresis was used. $\mathrm{A}_{260} / \mathrm{A}_{280}$ absorbance ratios were measured through spectrophotometer with the aim of determining genomic DNA purity, and purity and amount were calculated. $\mathrm{A}_{260} / \mathrm{A}_{280} \mathrm{~nm}$ absorbance ratio of 1,8 signifies a pure DNA sample. Lower values indicate contamination by proteins; the presence of RNA increases the ratio above 2,0 (Sambrook et al., 1989; Puchooa and Khoyratty, 2004). When the $\mathrm{A}_{260} / \mathrm{A}_{230} \mathrm{~nm}$ ratio is greater than 1,8 the DNA preparations are free from contaminations by polysaccharides (Peterson et al., 1997; Singh et al., 1999; Chen and Ronald, 1999; Ahmad et al., 2004; Aleskic et al., 2012). Table 1 illustrates the spectrophotometric measurements and purity levels and amounts of the genomic DNAs of Inula taxa.

\section{PCR amplifications}

ITS (nrDNA), trnL-F and $n d b \mathrm{~F}$ (cpDNA) primers were used in multiplying gDNAs obtained with the aim of determining the suitability degree of DNA isolated from the samples for PCR reactions. Amplification of the whole ITS region (ITS1 + 5.8S+ ITS2) was performed with primers ITS5A 5' CCTTATCATT'TAGAGGAAGGAG 3' and ITS4 5'TCCTCCGCTTATTGATATGC 3' (White et al., 1990). The amplification process was performed in $25 \mu \mathrm{l}$ of PCR reaction volume. Each PCR reaction contained $2.5 \mu \mathrm{l}$ of Taq buffer, $1.5 \mu \mathrm{l}$ of magnesium chloride $\left(\mathrm{MgCl}_{2}\right), 0.4 \mu \mathrm{l}$ of dNTP, $2.5 \mu \mathrm{l}$ for ITS4 and $2.5 \mu \mathrm{l}$ for ITS5 primers, $0.3 \mu \mathrm{l}$ of Taq DNA polymerase, $1.5 \mu \mathrm{l}$ of total genomic DNA (sometimes, $1 \mu \mathrm{l}, 0,5 \mu \mathrm{l}, 10^{-1}, 10^{-2}$ dilitued) and $11,8 \mu \mathrm{l}$ of $\mathrm{ddH}_{2} \mathrm{O}$. PCR amplification was performed with an initial denaturation step of $94^{\circ} \mathrm{C}$ for $5 \mathrm{~min}$, followed by 35 cycles of strand denaturation at $94^{\circ} \mathrm{C}$ for $1 \mathrm{~min}$, annealing at $50{ }^{\circ} \mathrm{C}$ for $45 \mathrm{~s}$, and primer extension at $72^{\circ} \mathrm{C}$ for $1 \mathrm{~min}$, and a final elongation at $72{ }^{\circ} \mathrm{C}$ for 5 min.trnL-F moleculer marker analyzed in this study belongs to the chloroplast genome (cpDNA). Polymerase Chain Reaction (PCR) amplifications of trnL-F cpDNA were performed using the primers designed by Taberlet et al. (1991) trnLe 5' GGTTCAAGTCCCTCTATCCC 3', trnFf 5'ATTTGAACTGGTGACACGAG 3' for all taxa included in this work. The amplification process was performed in $25 \mu \mathrm{l}$ of PCR reaction volume. Each PCR reaction contained $2.5 \mu \mathrm{l}$ of Taq buffer, $1.5 \mu \mathrm{l}$ of magnesium chloride $\left(\mathrm{MgCl}_{2}\right), 0.4 \mu \mathrm{l}$ of $\mathrm{dNTP}, 2.5 \mu \mathrm{l}$ for ITS4 and $2.5 \mu \mathrm{l}$ for ITS5 primers, $0,3 \mu \mathrm{l}$ of
Taq DNA polymerase, $1,5 \mu \mathrm{l}$ of total genomic DNA (sometimes, $1 \mu \mathrm{l}, 0,5 \mu \mathrm{l}, 10^{-1}, 10^{-2}$ diluted), and $11,8 \mu \mathrm{l}$ of $\mathrm{ddH}_{2} \mathrm{O}$. PCR amplification was performed with an initial denaturation step of $94^{\circ} \mathrm{C}$ for $5 \mathrm{~min}$, followed by 35 cycles of strand denaturation at $94^{\circ} \mathrm{C}$ for $30 \mathrm{sec}$, annealing at $53{ }^{\circ} \mathrm{C}$ for $45 \mathrm{~s}$, and primer extension at $72^{\circ} \mathrm{C}$ for $90 \mathrm{sec}$, and a final elongation at $72{ }^{\circ} \mathrm{C}$ for $8 \mathrm{~min} n d h F$ moleculer marker analyzed in this study belongs to the chloroplast genome (cpDNA). Polymerase Chain Reaction (PCR) amplifications of $n d b \mathrm{~F}$ cpDNA were performed using the primers designed by Olmstead and Sweere (1994) ndhF 972F5'GTCTCAATTGGGTTATATGA3',ndhF1603R5' GCATAGTATTTCCCGTTTCATGAGG 3'. The PCR amplification of $n d b \mathrm{~F}$ DNA was carried out in total reaction volume of $25 \mu \mathrm{l}$ containing $2.5 \mu \mathrm{l}$ of Taq buffer, $1.5 \mu \mathrm{l}$ of Magnesium chloride $\left(\mathrm{MgCl}_{2}\right), 0.4 \mu \mathrm{l}$ of $\mathrm{dNTP}, 2.5 \mu \mathrm{l}$ for $n d h 972 \mathrm{~F}$ and $2.5 \mu \mathrm{l}$ for $n d h 1603 \mathrm{R}$ primers, $0.3 \mu$ l of Taq DNA polymerase, $2.0 \mu \mathrm{l}$ of total genomic DNA, and $10.8 \mu \mathrm{l}$ of $\mathrm{ddH}_{2} \mathrm{O}$. The thermocycling profile consisted of an initial denaturation step at $94^{\circ} \mathrm{C}$ for $5 \mathrm{~min}$, followed by 35 cycles of $30 \mathrm{sec} .94^{\circ} \mathrm{C}, 45 \mathrm{sec}$. from 50 to $55^{\circ} \mathrm{C}, 1 \mathrm{~min}$ at $72^{\circ} \mathrm{C}$ and final extension step of $10 \mathrm{~min}$ at $72^{\circ} \mathrm{C}$. The amplification products were resolved by electrophoresis in $\% 0.8$ agarose gels. The bands were visualized using ethidium bromide staining.

\section{Results and Discussion}

After two different DNA isolation methods were applied on the Inula genus taxa, both genomic DNAs and PCR products were processed within $0.8 \%$ agarose gel at $120 \mathrm{~V}$ for 35 minutes, and photos of the gel were taken (Figure 1-8). Both phenol chloroform isoamyl alcohol method and commercial kit (Sigma) DNA isolation protocols were applied on 12 taxa of Inula genus in the study. It was found that the highest nanogram (ng) level of DNA is obtained through phenol chloroform isoamyl alcohol method in $1 \mu l$ stock. The highest and the lowest DNA amounts were obtained from $I$. macrocephala (908 ng) and I. heterolepis (148 ng), respectively with this method (Table 2). It was found that the highest and lowest DNA amounts obtained using commercial kit (SIGMA) were from I. fragilis (204 ng) and I. discoidea (86 ng), respectively (Table 2). When the $\mathrm{A}_{260} / \mathrm{A}_{280}$ absorbance rates of the DNA are examined, it was seen that the highest and the lowest purity degrees in gDNAs obtained through commercial kit isolation were observed in I.fragilis (1.457) and I.macrocephala (1.046), respectively. The highest and lowest purity degrees in gDNAs obtained through phenol chloroform isoamyl alcohol were observed in I.aucheriana (1.337) and I.salicina (1.023) samples, respectively (Table 2). When the gel images obtained from DNA isolations were examined, it was seen that the DNA bands obtained through phenol chloroform isoamyl alcohol method were brighter compared to the ones, which were obtained through commercial kit (SIGMA) method. It was also found that the amount of DNA obtained through phenol chloroform isoamyl alcohol method is higher than the amount obtained through commercial kit (SIGMA) in all samples; however, PCR results were worse in the DNAs obtained through phenol chloroform isoamyl alcohol (Table 2).

In PCR performed by using primers specific to nrDNA, ITS and cpDNA (trnL-F and $n d h \mathrm{~F}$ ) regions, DNA samples 
Table 2. Spectrophotometric measurements, purity amounts, and DNA amounts of the DNAs belonging to the Inula taxa collected (C: Commercial Kit (Sigma), F: Phenol-cloroform isoamil)

\begin{tabular}{|c|c|c|c|c|c|c|c|}
\hline Taxa & $\begin{array}{c}\text { Plant } \\
\text { amount } \\
(\mathrm{g})\end{array}$ & A260 & A280 & A230 & A260/280 & A260/230 & DNA amounts (ng) \\
\hline I. anatolica & 0,96 & $\begin{array}{l}0,056(\mathrm{C}) \\
0,090(\mathrm{~F})\end{array}$ & $\begin{array}{l}0,051(\mathrm{C}) \\
0.084(\mathrm{~F})\end{array}$ & $\begin{array}{l}0.096(\mathrm{C}) \\
0.142(\mathrm{~F})\end{array}$ & $\begin{array}{l}1.098(\mathrm{C}) \\
1.071(\mathrm{~F})\end{array}$ & $\begin{array}{l}0.583(\mathrm{C}) \\
0.633(\mathrm{~F})\end{array}$ & $\begin{array}{l}112(\mathrm{C}) \\
180(\mathrm{~F})\end{array}$ \\
\hline I. fragilis & 0,95 & $\begin{array}{l}0.102(\mathrm{C}) \\
0.125(\mathrm{~F})\end{array}$ & $\begin{array}{l}0.070(\mathrm{C}) \\
0.114(\mathrm{~F})\end{array}$ & $\begin{array}{l}0.177(\mathrm{C}) \\
0.192(\mathrm{~F})\end{array}$ & $\begin{array}{l}1.457(\mathrm{C}) \\
1.096(\mathrm{~F})\end{array}$ & $\begin{array}{l}0.576(\mathrm{C}) \\
0.651(\mathrm{~F})\end{array}$ & $\begin{array}{l}204(\mathrm{C}) \\
250(\mathrm{~F})\end{array}$ \\
\hline I.sechmenii & 0,82 & $\begin{array}{l}0.051(\mathrm{C}) \\
0.284(\mathrm{~F})\end{array}$ & $\begin{array}{l}0.048(\mathrm{C}) \\
0.252(\mathrm{~F})\end{array}$ & $\begin{array}{l}0.083(\mathrm{C}) \\
0.398(\mathrm{~F})\end{array}$ & $\begin{array}{l}1.062(\mathrm{C}) \\
1.126(\mathrm{~F})\end{array}$ & $\begin{array}{l}0.614(\mathrm{C}) \\
0.713(\mathrm{~F})\end{array}$ & $\begin{array}{l}102(\mathrm{C}) \\
568(\mathrm{~F})\end{array}$ \\
\hline I.mariae & 0,89 & $\begin{array}{l}0.051(\mathrm{C}) \\
0.167(\mathrm{~F})\end{array}$ & $\begin{array}{l}0.045(\mathrm{C}) \\
0.145(\mathrm{~F})\end{array}$ & $\begin{array}{l}0.113(\mathrm{C}) \\
0.227(\mathrm{~F})\end{array}$ & $\begin{array}{l}1.133(\mathrm{C}) \\
1.151(\mathrm{~F})\end{array}$ & $\begin{array}{l}0.451(\mathrm{C}) \\
0.735(\mathrm{~F})\end{array}$ & $\begin{array}{l}102(\mathrm{C}) \\
334(\mathrm{~F})\end{array}$ \\
\hline I.heterolepis & 0,81 & $\begin{array}{l}0.054(\mathrm{C}) \\
0.074(\mathrm{~F})\end{array}$ & $\begin{array}{l}0.050(\mathrm{C}) \\
0.068(\mathrm{~F})\end{array}$ & $\begin{array}{l}0.098(\mathrm{C}) \\
0.110(\mathrm{~F})\end{array}$ & $\begin{array}{l}1.080(\mathrm{C}) \\
1.088(\mathrm{~F})\end{array}$ & $\begin{array}{l}0.551(\mathrm{C}) \\
0.672(\mathrm{~F})\end{array}$ & $\begin{array}{l}108(\mathrm{C}) \\
148(\mathrm{~F})\end{array}$ \\
\hline I.macrocephala & 0,90 & $\begin{array}{l}0.068(\mathrm{C}) \\
0.454(\mathrm{~F})\end{array}$ & $\begin{array}{l}0.065(\mathrm{C}) \\
0.399(\mathrm{~F})\end{array}$ & $\begin{array}{l}0.174(\mathrm{C}) \\
0.622(\mathrm{~F})\end{array}$ & $\begin{array}{l}1.046(\mathrm{C}) \\
1.137(\mathrm{~F})\end{array}$ & $\begin{array}{l}0.390(\mathrm{C}) \\
0.729(\mathrm{~F})\end{array}$ & $\begin{array}{l}136(\mathrm{C}) \\
908(\mathrm{~F})\end{array}$ \\
\hline I.britannica & 0,96 & $\begin{array}{l}0.058(\mathrm{C}) \\
0.102(\mathrm{~F})\end{array}$ & $\begin{array}{l}0.050(\mathrm{C}) \\
0.091(\mathrm{~F})\end{array}$ & $\begin{array}{l}0.089(\mathrm{C}) \\
0.167(\mathrm{~F})\end{array}$ & $\begin{array}{l}1.160(\mathrm{C}) \\
1.120(\mathrm{~F})\end{array}$ & $\begin{array}{l}0.651(\mathrm{C}) \\
0.610(\mathrm{~F})\end{array}$ & $\begin{array}{l}116(\mathrm{C}) \\
204(\mathrm{~F})\end{array}$ \\
\hline I.salicina & 0,93 & $\begin{array}{l}0.069(\mathrm{C}) \\
0.133(\mathrm{~F})\end{array}$ & $\begin{array}{l}0.056(\mathrm{C}) \\
0.130(\mathrm{~F})\end{array}$ & $\begin{array}{l}0.257(\mathrm{C}) \\
0.208(\mathrm{~F})\end{array}$ & $\begin{array}{l}1.232(\mathrm{C}) \\
1.023(\mathrm{~F})\end{array}$ & $\begin{array}{l}0.268(\mathrm{C}) \\
0.639(\mathrm{~F})\end{array}$ & $\begin{array}{l}138(\mathrm{C}) \\
266(\mathrm{~F})\end{array}$ \\
\hline I.inuloides & 0,93 & $\begin{array}{l}0.068(\mathrm{C}) \\
0.157(\mathrm{~F})\end{array}$ & $\begin{array}{l}0.057(\mathrm{C}) \\
0.143(\mathrm{~F})\end{array}$ & $\begin{array}{l}0.108(\mathrm{C}) \\
0.260(\mathrm{~F})\end{array}$ & $\begin{array}{l}1.192(\mathrm{C}) \\
1.097(\mathrm{~F})\end{array}$ & $\begin{array}{l}0.629(\mathrm{C}) \\
0.603(\mathrm{~F})\end{array}$ & $\begin{array}{l}136(\mathrm{C}) \\
314(\mathrm{~F})\end{array}$ \\
\hline $\begin{array}{l}\text { I.helenium subsp. } \\
\text { orgyalis }\end{array}$ & 0,91 & $\begin{array}{l}0.060(\mathrm{C}) \\
0.114(\mathrm{~F})\end{array}$ & $\begin{array}{l}0.051(\mathrm{C}) \\
0.102(\mathrm{~F})\end{array}$ & $\begin{array}{l}0.094(\mathrm{C}) \\
0.177(\mathrm{~F})\end{array}$ & $\begin{array}{l}1.176(\mathrm{C}) \\
1.117(\mathrm{~F})\end{array}$ & $\begin{array}{l}0.638(\mathrm{C}) \\
0.644(\mathrm{~F})\end{array}$ & $\begin{array}{l}120(\mathrm{C}) \\
228(\mathrm{~F})\end{array}$ \\
\hline I.aucheriana & 0,89 & $\begin{array}{l}0.053(\mathrm{C}) \\
0.115(\mathrm{~F})\end{array}$ & $\begin{array}{l}0.047(\mathrm{C}) \\
0.086(\mathrm{~F})\end{array}$ & $\begin{array}{l}0.097(\mathrm{C}) \\
0.145(\mathrm{~F})\end{array}$ & $\begin{array}{l}1.127(\mathrm{C}) \\
1.337(\mathrm{~F})\end{array}$ & $\begin{array}{l}0.546(\mathrm{C}) \\
0.793(\mathrm{~F})\end{array}$ & $\begin{array}{l}106(\mathrm{C}) \\
230(\mathrm{~F})\end{array}$ \\
\hline I.discoidea & 0,97 & $\begin{array}{l}0.043(\mathrm{C}) \\
0.277(\mathrm{~F})\end{array}$ & $\begin{array}{l}0.033(\mathrm{C}) \\
0.264(\mathrm{~F})\end{array}$ & $\begin{array}{l}0.068(\mathrm{C}) \\
0.471(\mathrm{~F})\end{array}$ & $\begin{array}{l}1.303(\mathrm{C}) \\
1.049(\mathrm{~F})\end{array}$ & $\begin{array}{l}0.632(\mathrm{C}) \\
0.588(\mathrm{~F})\end{array}$ & $\begin{array}{l}86(\mathrm{C}) \\
554(\mathrm{~F})\end{array}$ \\
\hline
\end{tabular}

Table 3. PCR amplification results of ITS, $t r n \mathrm{~L}-\mathrm{F}$ and $n d h \mathrm{~F}$ primers and success rates

\begin{tabular}{|c|c|c|c|c|c|c|c|c|c|}
\hline \multirow[b]{2}{*}{ Isolation Protocol } & \multicolumn{2}{|c|}{ nrDNA (ITS) } & \multicolumn{2}{|c|}{ cpDNA $(n d b \mathrm{~F})$} & \multicolumn{2}{|c|}{ cpDNA (trnL-F) } & \multicolumn{3}{|c|}{ Success rates } \\
\hline & + band & - band & + band & - band & + band & - band & ITS & $n d h \mathrm{~F}$ & $\operatorname{trn} \mathrm{L}-\mathrm{F}$ \\
\hline $\begin{array}{l}\text { Phenol Chloroform } \\
\text { Isoamyl Alcohol }\end{array}$ & 3 & 9 & 5 & 7 & 4 & 8 & $\% 25$ & $\% 41$ & $\% 33$ \\
\hline Commercial Kit & 9 & 3 & 11 & 1 & 10 & 2 & $\% 75$ & $\% 91$ & $\% 83$ \\
\hline
\end{tabular}

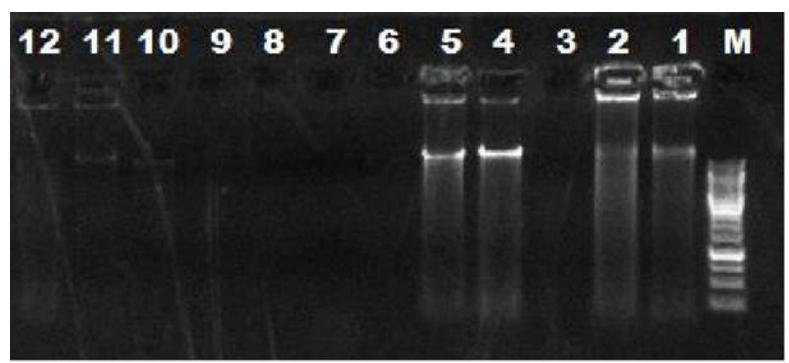

Fig. 1. Gel image of Inula gDNA's obtained by Phenol Chloroform Isoamyl Alcohol Protocol 1. I. anatolica, 2. I. fragilis, 3. I. sechmenii, 4. I. mariae, 5. I. heterolepsis, 6. I. macrocephala, 7. I. britannica, 8. I. salicina, 9. I. inuloides, 10. I. belenium subsp. orgyalis, 11. I. aucheriana, 12. I. discoidea

obtained with commercial kit (SIGMA) gave better results. ITS PCR results of the DNAs obtained through phenol isoamyl alcohol method gave positive results in only 3 out of 12 samples. A test was performed using different amounts of gDNA (0.5ul, 1ul, 2ul, 2.5ul) while isolation mixture was being prepared. However, the result remained the same. PCR success rate in phenol chloroform isoamyl alcohol method based on ITS primers was $25 \%$ (Table 3 ). PCR procedure of the gDNAs obtained through commercial kit (SIGMA) was very successful

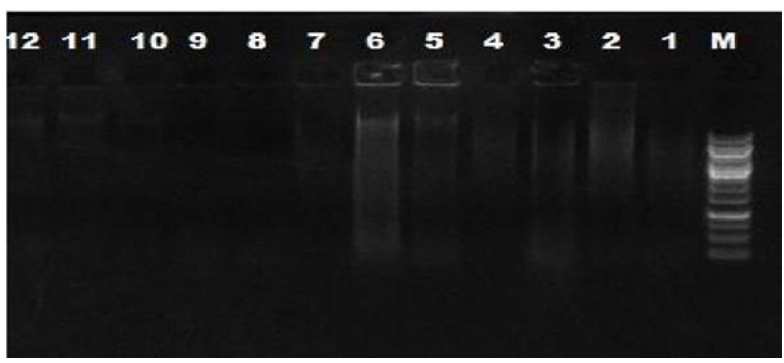

Fig. 2. Gel image of Inula gDNA's obtained by Comercial Kit.

1. I. anatolica, 2. I. fragilis, 3. I. sechmenii, 4. I. mariae,

5. I. heterolepsis, 6. I. macrocephala, 7. I. britannica, 8. I. salicina, 9. I. inuloides, 10. I. helenium subsp. orgyalis, 11. I. aucheriana, 12. I. discoidea

and while 9 out of 12 samples gave positive results, no result was obtained in 3 samples. Success rate of PCR rose to $75 \%$ with this method (Table 3). When PCR photos obtained using primers specific to cpDNA $n d b \mathrm{~F}$ regions of gDNAs obtained through phenol chloroform isoamyl alcohol method were examined, it was seen that only 5 samples gave positive results and no result was obtained from 7 samples. In this case, PCR success rate became $41 \%$ (Table 3). However, when PCR results of gDNAs obtained through commercial kit (SIGMA) 
448

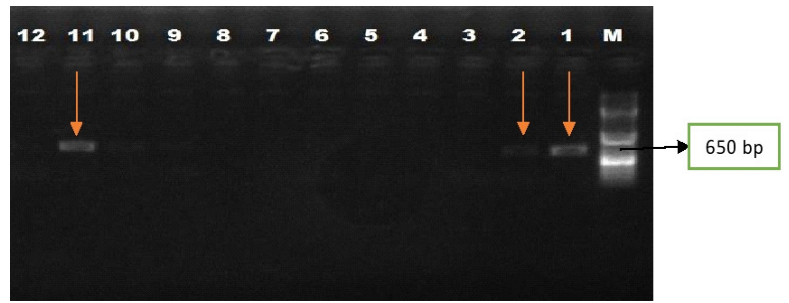

Fig. 3. Gel image of ITS primer amplified Inula gDNA's by Phenol Choroform Isoamyl Alcohol Protocol1. I. anatolica, 2. I. fragilis, 3. I. sechmenii, 4. I. mariae, 5. I. heterolepsis, 6. I. macrocephala, 7. I. britannica, 8. I. salicina, 9. I. inuloides, 10 . I. belenium subsp. orgyalis, 11. I. aucheriana, 12. I. discoidea

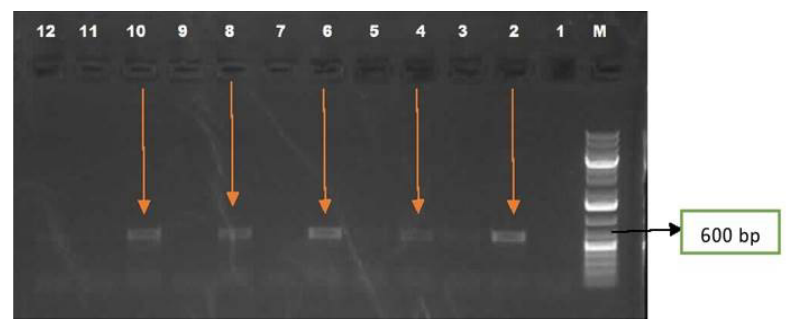

Fig. 5. Gel image of ndhF primer amplified Inula gDNA's by Phenol Choroform Isoamyl Alcohol Protocol 1. I. anatolica, 2. I. fragilis, 3. I. sechmenii, 4. I. mariae, 5. I. heterolepsis, 6. I. macrocephala, 7. I. britannica, 8. I. salicina, 9. I. inuloides, 10. I. helenium subsp. orgyalis, 11. I. aucheriana, 12. I. discoidea

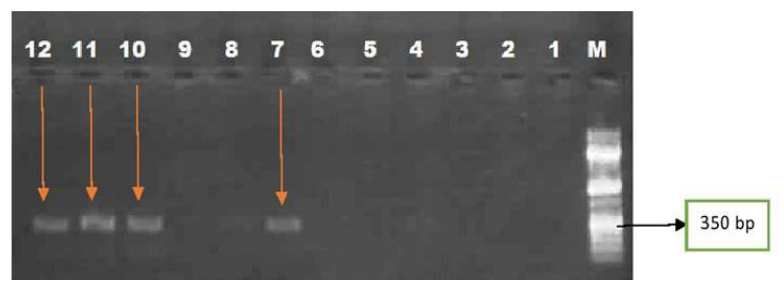

Fig. 7. Gel image of trnL-F primer amplified Inula gDNA's by Phenol Choroform Isoamyl Alcohol Protocol 1. I. anatolica, 2. I. fragilis, 3. I. sechmenii, 4. I. mariae, 5. I. heterolepsis, 6. I. macrocephala, 7. I. britannica, 8. I. salicina, 9. I. inuloides, 10. I. helenium subsp. orgyalis, 11. I. aucheriana, 12. I. discoidea

method were examined, it was seen that no result was obtained only in 1 sample and highly positive results were obtained in 11 samples. In this case, PCR success rate became almost $91 \%$. According to the PCR results obtained using primers specific to cpDNA trnL-F regions of gDNAs obtained through phenol chloroform isoamyl alcohol method, positive results were obtained from 4 samples and PCR success rate was 33\% (Table 3). When the PCR results of gDNAs obtained through commercial kit (SIGMA) method were examined, no positive results were obtained only from 2 samples, whereas 10 samples gave very positive results. In this case, PCR success rate rose to 83\% (Table 3).

Previous studies performed in the past applied different genomic DNA isolation methods on plants, likens and algae and new techniques were developed. Cingilli and Akçin (2005)

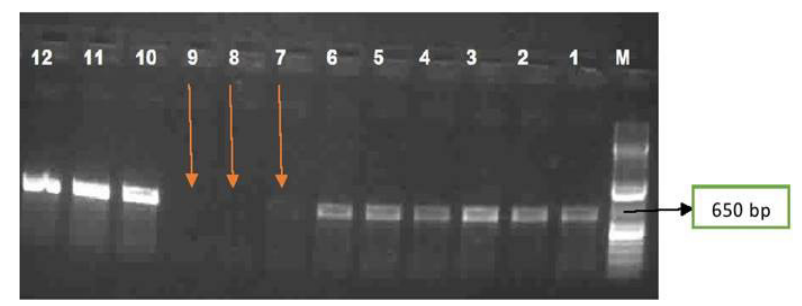

Fig. 4. Gel image of ITS primer amplified Inula gDNA's by Comercial Kit.1. I. anatolica, 2. I. fragilis, 3. I. sechmenii, 4. I. mariae, 5. I. heterolepsis, 6. I. macrocephala, 7. I. britannica, 8. I. salicina, 9. I. inuloides, 10 . I. helenium subsp. orgyalis, 11. I. aucheriana, 12. I. discoidea

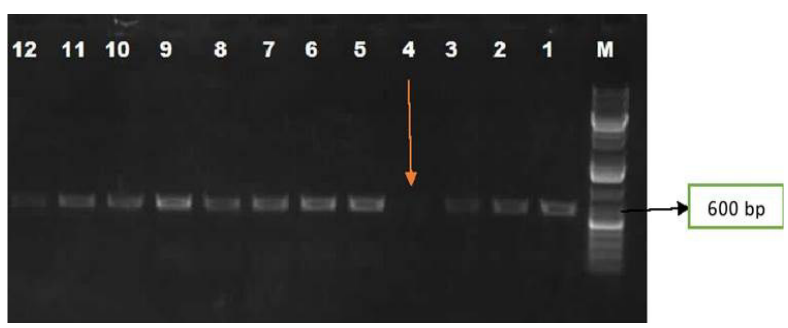

Fig. 6. Gel image of ndhF primer amplified Inula gDNA's by Commercial Kit. 1. I. anatolica, 2. I. fragilis, 3. I. sechmenii, 4. I. mariae, 5. I. heterolepsis, 6. I. macrocephala, 7. I. britannica, 8. I. salicina, 9. I. inuloides, 10 . I. helenium subsp. orgyalis, 11. I. aucheriana, 12. I. discoidea

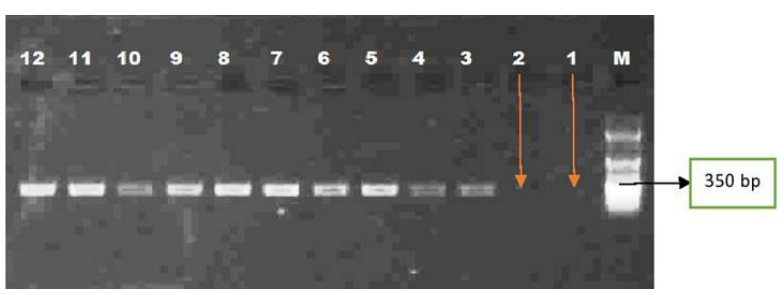

Fig. 8. Gel image of trnL-F primer amplified Inula gDNA's by Commercial Kit. 1. I. anatolica, 2. I. fragilis, 3. I.

sechmenii, 4. I. mariae, 5. I. heterolepsis, 6. I. macrocephala, 7. I. britannica, 8. I. salicina, 9. I. inuloides, 10 . I. helenium subsp. orgyalis, 11. I. aucheriana, 12. I. discoidea

applied mini-prep CTAB and micro-prep CTAB methods on 49 chick peas (Cicer ssp.). At the end of the study, higher amount and higher quality genomic DNAs were obtained in comparison with the genomic DNAs obtained through mini prep method. The method was found to be highly economic with respect to labor force, cost and chemical material usage. It was also proven with band profiles through which suitable pure DNA was obtained by amplifying chick pea gDNAs obtained through mini prep CTAB protocol by using UBC181 RAPD primers. Aras and Cansaran (2006) applied a different genomic DNA isolation method for a series of analysis in herbarium samples of some lichens. In the study, as a result of the comparison of the protocol based on hexadecyltrimethylammonium bromide (CTAB) and the protocol based on SDS it was found that gDNAs obtained 
through $\mathrm{CTAB}$ method were more efficient for lichens. Şimşek et al. (2008) obtained gDNA by applying MiniPrep DNA isolation method and the modified versions of this method on hazelnut, avocado, persimmon, tangerine. In the methods tested, isolation buffers were prepared in a way in which $\mathrm{CTAB}$ is single, CTAB-PVP are together, CTAB- SDS are together and SDS is single. Concentration and quality of these DNAs obtained after this isolation method were compared and interpreted. Ogunkanmi et al. (2008) obtained genomic DNA from different pepper tissues by revising DNA isolation protocol modified by Dellaporte et al. (1983). During isolation, no liquid nitrogen or phenol chloroform extraction was required. It was determined that $\mathrm{A}_{260} / \mathrm{A}_{280}$ absorbance ratio of gDNAs obtained from tissues was between 1.7 and 1.9. It was revealed that DNA amount obtained from fleshy mesocarp tissue was higher than the DNA amount obtained from the seeds of the same weight. PCR amplification was performed by using RAPD primers. As a consequence, it was revealed that PCR and RAPD analyses performed with less efficient DNAs were more efficient. Tuney et al. (2010) used modified $\mathrm{CTAB}$ method on the brown marine algae and obtained genomic DNA. PCR was performed on gDNA using 4 different RAPD primers. The results indicated that CTAB method applied on the marine algae were suitable for molecular analysis. Roychowdhury et al. (2012) isolated genomic DNA from Oryza sativa (rice) tissues (seedling, leaf, root, grain, kernel, straw and embryo genic callus). $\mathrm{A}_{260} / \mathrm{A}_{280}$ absorbance ratios of the gDNAs obtained were measured. No toxic chemicals such as liquid nitrogen or phenol were used in the DNA isolation method that they developed and they obtained a DNA efficient for PCR from a low amount of plant tissue. At the end of the analysis, it was revealed that the best purity degree was obtained from callus tissues of gDNA (1.77), maximum DNA concentration was $9.52 \mathrm{ug} / \mathrm{ml}$ and was obtained from the seed tissues. The gDNAs isolated were multiplied via rice microsatellite (RM). Microsatellite based DNA fingerprint revealed that DNAs obtained from different tissues provided repeatable bands. Aleskic et al. (2012) developed a simple and efficient DNA isolation method for Salvia officinalis L. Of the gDNAs that they obtained, the mean efficiency was found to be $330.6 \mathrm{ugDNA} / \mathrm{g}, \mathrm{A}_{260} / \mathrm{A}_{280}$ ratio was found to be 1,909 and $\mathrm{A}_{260} / \mathrm{A}_{230}$ ratio was found to be 1.894. Later, gDNAs were subjected to PCR amplification using primers specific to nuclear $26 \mathrm{~S} \mathrm{rDNA}$ and chloroplast rps 16-trnK regions. As a result, they stated that the DNA isolation protocol that they performed gave positive bands and could be used in the DNA based molecular studies to be carried out in the future. Poyraz (2014) obtained gDNA by using CTAB method modified by Doyle and Doyle (1987) from seeds of Nigella sativa L. (Black cumin) plant. About $20 \mathrm{ng}$ genomic DNA was obtained from each $150 \mathrm{mg}$ dry seed. No ultracentrifuge or column purification was used during isolation. The gDNAs obtained were subjected to PCR amplification by using RAPD and ISSR markers. As a result, it was found that gDNAs obtained were efficient and suitable for PCR amplification.

\section{Conclusions}

Consequently, in this study, two different genomic DNA isolation methods were applied on 12 taxa of Inula genus that is distributed throughout Turkey, and PCR amplification was performed using primers specific to ITS, trnL-F and $n d h \mathrm{~F}$ regions. Various DNA isolation methods are available for different species and genera. It is harder to apply phenol choloform isoamyl alcohol method in comparison with commercial kit (SIGMA), however, it is cost-efficient. On the other hand, it is easy to apply commercial kit method and it is advantageous in terms the fact that it is time saving and the chemicals used are pure. In our study, it was revealed that the amount of the genomic DNAs obtained through phenol method was higher than the genomic DNA amount obtained through commercial kit. However, PCR results obtained by using primers specific to ITS, trnL-F and $n d b \mathrm{~F}$ (972F-1603R) regions indicated that the highest efficiency was achieved from genomic DNAs by using commercial kit with respect to band profiles. Inula samples, which are the materials of the study, contain secondary metabolites rich in allochtones and terpenes. For this reason, phenolic compounds within gDNAs could not be purified through phenol chloroform isoamyl alcohol method and it is considered that it affects PCR amplification. However, that kit method purifies these compounds in an efficient manner rendered PCR amplification more successful. It is thought that washing with Wash solution twice at gDNA isolation step with kit was effective in terms of clearing the pure DNA of the secondary metabolites. At the last step of phenol isoamyl alcohol method in the study, washing with $90 \%$ ETOH was performed twice. However, the desirable result could not be obtained. For this reason, PCR amplification of gDNAs obtained through kit method was found to be more successful than PCR amplification of gDNAs obtained through phenol chloroform method. This study provides information concerning which method is more suitable in DNA based studies to be conducted on Inula genus or different plant genera.

\section{Acknowledgements}

The research was supported by the Balikesir University under grant (2013/92).

\section{References}

Ahmad SM, Ganaie MM, Qazi PH, Verma V, Basir SF, Qazi GN (2004). Rapid DNA isolation protocol for angiospremic plants. Bulg. J. Plant. Physiol 30:25-3.

Ahmed AA, Mohamed HA, Tzakou O, Petropoulou A, Hassan ME, ElMaghraby AM, Zeller PK (2003). Terpenes from Inula vesbascifolia Phytochemistry 62:1191-1194.

Akhtar S, Bhat MA, Wani SA, Bhat KA, Chalkoo S, Mir MR, Wani SA (2010). Marker assisted selection in rice.Journal of Phytology 2:66-81.

Aleskic MJ, Stojanovic D, Banovic B, Jancic RA (2012). Simple and efficient DNA isolation method for Salvia officinalis. Biochemical Genetics 50: 881-892.

Aras S, Cansaran D (2006). Isolation of DNA for sequence analysis from herbarium material of some lichen specimens. Turkish Journal of Botany 30:449-453.

Bailes SM, Devers JJ, Kirby JD, Rhoads DD (2007). An inexpensive, simple protocol for DNA isolation from blood for high-throughput genotyping by polymerase chain reaction or restiriction endonuclease digestion. Poultry Science 86:102-106.

Chen DH, Ronald PC (1999). A rapid DNA minipreparation method 
450

suitable for AFLP and other PCR applications. Plant Molecular Biology Reporter 17:53-57.

Cingilli H, Akçin A (2005). High Quality DNA isolation method for chickpeagenotypes. Turkish Journal of Biology 29:1-5.

Dellaporta SL, Wood J, Hicks JB (1983). A plant DNA minipreparation: Version II. Plant Plant Molecular Biology Reporter 1:19-21.

Doyle JJ, Doyle JL (1987). A rapid DNA isolation procedure from small quantities offresh leaf tissue. Phytochemical Bulletin 19:11-15.

Dwivedi SL, Crouch JH, Mackill DJ, Xu Y, Blair M, Ragot H, Upadhyaya D, Ortiz R (2007). The molecularization of public sector crop breeding: progress, problems, and prospects. Advances in Agronomy 95:163-318.

FangG, HammarS, Grumet R(1992). A quick and inexpensive method for removing polysaccharides from plant genomic DNA. Biotechniques 13:52-54.

Francia E, Tacconi G, Crosatti C, Barabaschi D, Bulgarelli D, Dall'Aglio E, Vale $G$ (2005). Marker assisted selection in crop plants. PCTOC 82 317-342.

Kermekchiev MB, Lyubka IK, Erika EV, Barnes WM (2009). Mutants of Taq DNA polymerase resistant to PCR inhibitors allow DNA amplification from whole blood and crude soil samples. Nucleic Acid Research 37:e40.

Lee M (1995). DNA markers and plant breeding programs. Advences in Agronomy 55:265-344.

Liu XQ, Wang L, Chen S, Lin F, Pan QH (2005). Genetic and physical mapping of Pi36(t), a novel rice blast resistance gene located on rice chromosome 8. Molecular Genetics and Genomics 274:394401.

Mackill DJ (2007). Molecular markers and marker-assisted selection in rice. In: Varshney RK, Tuberosa R (Eds). Genomics-assisted crop improvement. Springer Netherlands pp 147-168.

Ogunkanmi LA, Oboh B, Onifade B, Ogunjobi AA, Taiwo IA, Ogundipe OT (2008). An improved method of extracting genomic DNA from preserve tissue of Capsicum annuum for PCR amplification. Eurasian Journal Bioscience 2:115-119.

Olmstead RG, Sweere JA (1994). Combining data in phylogenetic systematics: an empirical approach using three molecular data sets in the Solanaceae. Systematic Biology 43: 467-481.

Peterson DG, Boehm KS, Stack SM (1997). Isolation of milligram quantities of nuclear DNA from tomato (Lycopersicon esculentum), a plant containing high levels of polyphenolic compounds. Plant Molecular Biology Reporter 15:148-153

Pirttila AM, Hirsikorpi M, Kamarainen T, Jaakola L, Hohtola A (2001). DNA isolation methods for medicinal and aromatic plants. Plant Molecular Biology Reporter 19:273-273.
Poyraz İ (2014). An efficient DNA solation method from Nigella sativa L (Ranunculaceae) seeds for RAPD and ISSR analysis. Bilecik Şeyh Edebali Üniversitesi Fen Bilimleri Dergisi 1:22-27.

Puchooa D, Khoyratty SSS (2004). Genomic DNA extraction from Victoria amazonica. Plant Molecular Biology Reporter 22:195-196.

Qi LJ, Fu Y, Shi WX, Wu BY, Wang ZY, Zhang QD, Shi WQ (2008). Sesquiterpene lactones and their anti-tumor activity from the flowers of Inula britannica. Letters in Drug Design and Discovery 5:433-436.

Roychowdhury R, Karmakar J, Dey N (2012). PCR-compatible genomic DNA isolation from different tissues of rice (Oryza sativa) for SSR fingerprinting. Eurasian Journal Bioscience 6:85-90.

Sambrook J, Fritsch EF, Maniatis T (1989). Molecular cloning, a laboratory manual. Cold Spring Harbor Laboratory Press, New York.

Sant VJ, Patankar AG, Sarode ND (1999). Potential of DNA markers in detecting divergence and in analyzing heterosis in Indian elite chickpea cultivars. Theoretical and Applied Genetics 98:1217-1225.

Shao Y, Bai N, Zhou B (1996). Kaurane gycosides from Inula britannica. Phytochemistry 42:783-786.

Singh M, Bandana, Ahuja PS (1999). Isolation and PCR amplification of genomic DNA from market samples of dry tea. Plant Molecular Biology Reporter 17:171-178.

Şimşek Ö, Karaat FE, Serçe S, Kaçar YA (2008). Bazı Meyve Türlerinde DNA İzolasyon Yöntemlerinin Etkinliğinin Karşlaşturlması. DERİM 25:59-69.

Taberlet P, Gielly L, Pautou G, Bouvet J (1991). Universal primers for amplification of three non-coding regions of chloroplast DNA. Plant Molecular Biology 17:1105-1109.

Tuney İ, Sukatar A (2010). DNA extraction protocol from Brown Algae. Biodicon 3:51-55.

Ulubelen A, Öksüz S, Gören N (1987). Sesquiterpene acids from Inula viscosa. Phytochemistry26:1223-1224.

Vajs V, Jeremic D, Milosavljevic S, Macura S (1989). Sesquiterpene lactones from Inula helenium. Phytochemistry28:1763-1764.

Vural HC, Akcin A (2010). Molecular analysis of chickpea species through molecular markers. Biotechnology and Biotechnological Equipment 24:1828-1832.

White TJ, Bruns T, Lee S, Taylor J (1990). Amplification and direct sequencing of fungal ribosomal RNA genes for phylogenetics. In: PCR Protocols: aguide to methods and applications. Innis MA, Gelfand DH, Sninsky JJ, White TJ (Eds). Academic Press, New York, USA pp 315322. 